\title{
THE EFFECTS OF A SHOPPING MALL ON HOUSING PRICES: A CASE STUDY IN HANGZHOU
}

\author{
Ling ZHANG ${ }^{1}$, Jiantao ZHOU1, Eddie C. M. HUI ${ }^{2}$, Haizhen WEN ${ }^{1, *}$ \\ ${ }^{1}$ Center for Real Estate Studying, Department of Civil Engineering, Zhejiang University, China \\ 2 Department of Building and Real Estate, The Hong Kong Polytechnic University, Hung Hom, \\ Kowloon, Hong Kong, China
}

Received 4 December 2017; accepted 30 August 2018

\begin{abstract}
There are few studies on the externalities of shopping malls affecting the housing market. This study aims to discuss two issues: (1) What is the intensity of the impact of a shopping mall? (2) When does the external influence of a shopping mall begin to reveal itself? The West Intime Shopping Mall in Hangzhou offers a unique situation to research the questions. By dividing the study area into nine blocks, using hedonic price theory, and the price gradient approach with housing price data from 2011 to 2015, we found that in the space dimension, the mall exerted a significantly positive effect on the housing prices of nearby blocks. With the increase in distance from the mall, the positive effect decreased. There were more significantly positive effects in blocks far away from the city center. In the time dimension, the effects of West Intime did not reveal themselves until the mall had started to operate and gradually matured over time, implying that the mall did not have the obvious expected impact on housing prices before the mall had begun operating.
\end{abstract}

Keywords: shopping mall, housing price, price index, price gradient, hedonic models.

\section{Introduction}

With the suburbanization and economic growth occurring since the 1960s in the United States, shopping centers and malls have been spreading throughout cities, first in the suburbs, then in the downtown areas (Carter, 2009). Shopping malls have dramatically reshaped the retailing industry, providing the impetus for regional economic development and the improvement of living standards. Now, shopping malls are major centers of retail activity in the United States and around the world (Larsen, Shelton, \& Wright, 2015). In recent years, alongside urban development in China, shopping malls have grown quickly with urbanization, versatility, and convenience in transportation. Most malls deliver convenience to local residents and have strong influences on neighboring areas. Large-scale shopping malls have become attractive places to shop, visit, and spend time. Most malls have also increased their leisure activity components (Fasli, Riza, \& Erbilen, 2016).

There have been many types of studies focusing on the designs, functions, rents, and satisfactoriness of shopping malls (Carter, 2009). Some studies have discussed the role of shopping centers in societies and urban spaces, but most have not covered the externalities of shopping centers. Shopping malls can deliver commercial convenience to the surrounding residences, indirectly increasing the values of these properties in the housing market. Therefore, it makes sense to explore the effects of shopping malls on housing prices.

Compared to infrastructure, schools, and other public facilities, shopping malls are so complex that they may possess distinctive externalities. Sirpal (1994) and Des Rosiers, Lagana, Thériault, and Beaudoin (1996) discovered positive and negative effects at different distances from shopping malls. The externalities are directly related to the internalities, such as the scale, design and anchor tenants, of a mall. Moreover, the influence of a mall may change at different stages over time. Promotional advertising before a mall's construction may fuel a rise in housing prices while noise from the construction works could worsen the living conditions of residents and lower the housing prices. After a mall's completion, its external influence usually differs with the maturity of its operation and the establishment of word of mouth. Such externalities, particularly in terms of their scope and times of impacts on the housing

*Corresponding author. E-mail: wenhaizhen@263.net 
market, have been ignored by existing studies. This paper uses a single shopping mall as the object of study in order to observe the mall's impact on the housing prices of surrounding properties, incidence, impact time, and gradient changes. Both price indices for zones and price gradient analysis were used for estimation. The concept of the price gradient was used to analyze the temporal and spatial influences of the mall on housing prices.

The following section presents the literature review on shopping malls and related theories. Section 2 introduces the studied shopping mall and its surroundings. Section 3 discusses the methodology, variables, and data. Section 4 reports the findings. Last section presents the concluding remarks.

\section{Literature review}

The research on retail has been gradually enriched since the 1930s. Hotelling (1929) and Christaller (1933) initiated the research on central place theory and retail agglomeration, which are regarded as the theoretical foundations of shopping malls. This theory assumed that the consumer made a shopping trip for a single purpose and visited the nearest shopping center (Berry \& Garrison, 1958), but Golledge, Rushton, and Clark (1966) found that when consumers exhibited multipurpose shopping behavior, they did not always purchase goods or services at the nearest store or shopping mall. If two shopping areas were close enough, the consumer may choose a farther shopping mall with more functions rather than a closer one with fewer functions (Clark, 1968; Rushton, 1969). The retail agglomeration resulted, which can be explained by the utility maximization of consumers (Hotelling, 1929; De Palma, Ginsburgh, Papageorgiou, \& Thisse, 1985). Thereafter, many studies have emerged, with most of them focusing on the internal attributes, such as leasing, anchor tenants, and space allocation, of shopping malls. According to the studies concerning the leasing of shopping centers and the determinants of shopping center sales (Gatzlaff \& Ling, 1994; Mejia \& Benjamin, 2002), rents can indirectly reflect a mall's operating conditions. Sirmans and Guidry (1993) studied the market rents for shopping centers and found that customer drawing power was an important determinant, which was indicated by building area and age of the mall, as well as type of anchor tenant. Besides, a good location and an enclosed design always behave well. Through an extensive survey, Ooi and Sim (2007) affirmed that a large size and the presence of a famous cinema can enhance the draw power of a suburban mall. The extending works provided analyses of the problem of space allocation and agency behavior (Brueckner, 1993; Carter \& Haloupek, 2002). Other studies have been concerned with store types and business enterprise value. All these research focusing mainly on the insides of the shopping malls help to explain why some shopping malls are more attractive.

Compared with the rich research on shopping centers, there has been little research concerning about the external relations and influences of the malls. Based on their findings that the supply and demand attributes of shopping centers were spatially dependent, Ozuduru (2013) confirmed that shopping centers played an important role in urban growth. As shopping centers have moved towards becoming social gathering spaces, they have had a great impact on the urban lifestyles (Fasli et al., 2016). Some scholars have contributed to examining the role of shopping centers in society. Erkip (2005) conducted a survey using structured interviews and various observations. The statistical analyses showed that the proportion of customers who "come to the mall only for shopping" is $42.6 \%$ while the proportions of customers "for other activities" and "for browsing" are $44.3 \%$ and $51.1 \%$ respectively. It can be seen that the significance of a shopping mall for its surrounding residents lies not only in shopping, but also in the other values provided by the mall. Being multi-functional facilities and significant catalyst of urban, shopping malls have significant impacts on neighborhood.

The hedonic price model is widely used to examine housing prices at a micro-level. Housing prices are investigated by the characteristics of structure, neighborhood, and location (Freeman, 1981; Chau \& Chin, 2003; Mok, Chan, \& Cho, 1995). Hui, Chau, Pun, and Law (2007) investigated the effects of neighboring and environmental characteristics of a residential property on its market value and found that in Hong Kong, households are willing to sacrifice serenity for convenience. There are many studies discussing the externalities of public facilities, such as schools (Clark \& Herrin, 2000; Sedgley, Williams, \& Derrick, 2008) and parks (Weigher \& Zerbst, 1973; Wen, Bu, \& Qin, 2014a). More scholars have studied the impacts of locations involving rail transit (So, Tse, \& Ganesan, 1997) and transport accessibility (McMillan, Jarmin, \& Thorsnes, 1992; Henneberry, 1998), most of which have had significantly positive impacts on housing prices.

When using the hedonic theory to evaluate the price of neighborhood characteristics in housing price models, some of the previous studies considered shopping malls as one of the factors in commercial facilities. Generally, they used dummy or grade variables to consider whether there were any shopping malls around a property. Colwell, Gujral, and Coley (1985) first studied the effects of distances to shopping centers on housing prices. They concluded that shopping centers had positive effects on surrounding housing prices, because of their commercial convenience, but also had negative effects, such as noise, pollution and traffic congestion, at closer distances. Using 143 cases, Sirpal (1994) applied the quadratic function of distance to fit different effects, while Des Rosiers et al. (1996) applied the gamma function for fitting effects. Both studies supported Colwell's conclusion. In addition, they considered the sizes of shopping centers and found that size did have effects. A larger shopping center generated a wider scope of impacts. Song and Sohn (2007) integrated the distances to stores and shopping centers into a spatial accessibility index for retailing and found that higher spatial accessibility to re- 
tailing was capitalized into residential property values. Yu, Cho, and Kim (2012) created multiple driving time buffers instead of using simple Euclidean distances to reflect accessibility and capture the distance decay effects. The case study of the Turkey Creek Shopping Center showed that households placed a positive value on proximity to a shopping center with a travel time - distance of 3-20 minutes.

The above studies all concentrated on the influence mode restricted to spatial effects. However, some scholars have begun to examine the time effect in studies of public facilities, such as transportation projects. Yiu and Wong (2005) used location - time interactive items to study the impacts of a tunnel on housing prices in Hong Kong. They found that there were significant increases in prices even before the completion of the works. A study on the Chicago MRT Orange Line indicated that during the announcement period, housing prices had increased by $4.2 \%$. When the Line was under construction, the rate of increase doubled and increased up to $19.4 \%$ in the three years after the commencement of operations (McMillen \& McDonald, 2004). However, sometimes, the impact takes place until after a subway system commences operation (Loomis, Santiago, \& Lopez de Jesus, 2012).

While many studies use cross-sectional data to explore spatial influences, they cannot discern whether an impact is definitely caused by the object ( $\mathrm{Gu} \& \mathrm{Jia}, 2008$ ). There are some studies using time series data to capture the effects of time changes by dummy variables (McMillen \& McDonald, 2004). However, with this method, it is difficult to separate the impacts of price trends or policy interferences. To solve this problem, Coulson (1991), Chau and Ng (1998), Yiu and Tam (2004) proposed a price gradient method using location - time interactive items to measure changes in the price gradient, the concept of which was developed from a bid - rent curve (Alonso, 1964). Their empirical studies demonstrated that price gradient analysis was an effective method of characterizing the impacts of a study object.

As mentioned above, there has been much research on shopping malls, but inadequate research on their externalities. A few existing studies have taken operating shopping malls as research objects but have ignored the variant impacts on neighborhoods at different stages. In the rich studies of housing prices, the influences of shopping centers have not been paid sufficient attentions. To fill these gaps, this paper discusses two issues: (1) What is the extent of the impact of a shopping mall? (2) When does the external influence of a shopping mall begin to appear? The first issue was solved by the comparison of price gradients in different zones but the second was somewhat complex, so this study used location - time interactive items to capture the different impacts at different times.

\section{The West Intime Shopping Mall and study area}

The research object of this paper is the West Intime Shopping Mall, which is located in the northwest of Hangzhou on a straight line $7 \mathrm{~km}$ away from the city center. The construction of West Intime began in January 2011 and was completed in September 2013. The total construction area reached $289,000 \mathrm{~m}^{2}$ with more than 200 shops. The mall and its location provides a unique opportunity to observe the impact of a particular shopping center on its surrounding area. The development of the entire western area in the city began in the late 1990s. Because of the lack of regional planning, a large number of new residential communities had gathered, but commercial facilities were seriously inadequate. Before the construction of West Intime, there were only two medium-sized commercial facilities, i.e. Xicheng Square and Hangzhou Incity, which opened in 2004 and 2010, respectively, and were closer to the city center. The construction area of Xicheng Square was $55,393 \mathrm{~m}^{2}$ with 97 shops while that of Hangzhou Incity was $53,000 \mathrm{~m}^{2}$ with 96 shops. As for anchor tenants, West Intime has four anchor shops with high quality and a large area. In contrast, the other two shopping malls have almost no comparable anchor tenants. The basic data of these three shopping malls are shown in Table 1. The two most famous shopping malls in the city center are also included for reference.

The business data of shopping malls is difficult to gather, so this study used the turnover created by the biggest anchor tenant, Intime Department Store, to reflect the operating conditions of the mall (as shown in Table 2).

Table 1. The operating information of shopping malls

\begin{tabular}{|c|c|c|c|c|c|c|c|}
\hline \multirow[b]{2}{*}{ Mall name } & \multirow{2}{*}{$\begin{array}{c}\text { Total } \\
\text { construction } \\
\text { area } / \mathrm{m}^{2}\end{array}$} & \multirow{2}{*}{$\begin{array}{l}\text { Opening } \\
\text { date }\end{array}$} & \multicolumn{4}{|c|}{ Commercial activities } & \multirow[b]{2}{*}{ Anchor tenants } \\
\hline & & & Retail & Food & $\begin{array}{l}\text { Entert- } \\
\text { ainment }\end{array}$ & Service & \\
\hline West Intime & 289,000 & $2013 / 9 / 8$ & $58 \%$ & $20 \%$ & $20 \%$ & $2 \%$ & $\begin{array}{l}\text { Intime Department Store; } \\
\text { Siyo Rink; SAGA Luxury } \\
\text { Cinemas; PHYSICAL Fitness } \\
\text { Center }\end{array}$ \\
\hline Hangzhou Incity & 53,000 & $2010 / 2 / 1$ & $40 \%$ & $25 \%$ & $20 \%$ & $15 \%$ & Wal-Mart \\
\hline Xicheng Square & 55,393 & $2005 / 1 / 8$ & $56 \%$ & $14 \%$ & $25 \%$ & $5 \%$ & UME International Cinemas \\
\hline Hangzhou Tower & 140,000 & $1989 / 6 / 1$ & $80 \%$ & $10 \%$ & $5 \%$ & $5 \%$ & 1 \\
\hline Wulin Intime & 51,000 & $1998 / 11 / 16$ & $95 \%$ & $5 \%$ & / & I & 1 \\
\hline
\end{tabular}

Note: The data are from the China Real Estate Information Corporation's (CRIC) database, one of the largest real estate information databases in China. 
Table 2. Turn-Over of Intime Department Store

\begin{tabular}{|l|c|c|c|c|c|c|c|}
\hline & $\begin{array}{c}09 / 08 / 2013- \\
09 / 30 / 2013\end{array}$ & $\begin{array}{c}\text { Quarter 1, } \\
2014\end{array}$ & $\begin{array}{c}\text { Quarter 2, } \\
2014\end{array}$ & $\begin{array}{c}\text { Quarter 3, } \\
2014\end{array}$ & $\begin{array}{c}\text { Quarter 1, } \\
2015\end{array}$ & $\begin{array}{c}\text { Quarter 2, } \\
2015\end{array}$ & $\begin{array}{c}\text { Quarter 3, } \\
2015\end{array}$ \\
\hline Turn-Over/¥1000 & 14110 & 58855 & 50635 & 60885 & 80441 & 67767 & 70395 \\
\hline Year-on-year growth rate & $/$ & $/$ & $/$ & $/$ & $36.68 \%$ & $33.83 \%$ & $15.62 \%$ \\
\hline $\begin{array}{l}\text { Quarter on quarter } \\
\text { growth rate }\end{array}$ & $/$ & $/$ & $-13.97 \%$ & $20.24 \%$ & $/$ & $-15.76 \%$ & $3.88 \%$ \\
\hline
\end{tabular}

Note: The data are from the official website of Intime Department Store.

The turnover increased significantly from 2014 to 2015. In summary, West Intime fared well during the operating period due to the high-quality building, anchor tenants, and excellent operations.

To fully consider the impact of West Intime, the scope was expanded for the entire western city area, which is a long strip spanning $8 \mathrm{~km}$ from north to south and $4 \mathrm{~km}$ from west to east. The study area reaches Moganshan Road and Gucui Road in the east, Tianmushan Road in the south, Zijingang Road, Zijinghua Road, Jihong Road in the west, and Jindu North Road in the north. In general, this area belonged to the peripheral area of the main city at the beginning of the study period. There are mature communities to the east and south of the mall, while the city center is located to the southeast direction. There are mainly factories and old communities in the adjacent area northeast of the mall, where the housing deals are few. To the west of the study area is Zhejiang University and Xixi Wetland Park, which both occupy a large area. West Intime is located in the middle of the region $5 \mathrm{~km}$ in a straight line away from the farthest property. The southern area has been a newly-built urban commercial and residential area since the 1990s. The northern area developed later but has grown rapidly with vigorous performance in the real estate market during the past five years. So, most our housing transaction data are distributed in a north-south direction along the main street. On this basis, the study area was divided into nine blocks from south to north. Partitioning refers mainly to the distribution of the road network. Taking the quantity of the sample data into account at the same time, the southern area has adequate data (number of real estate

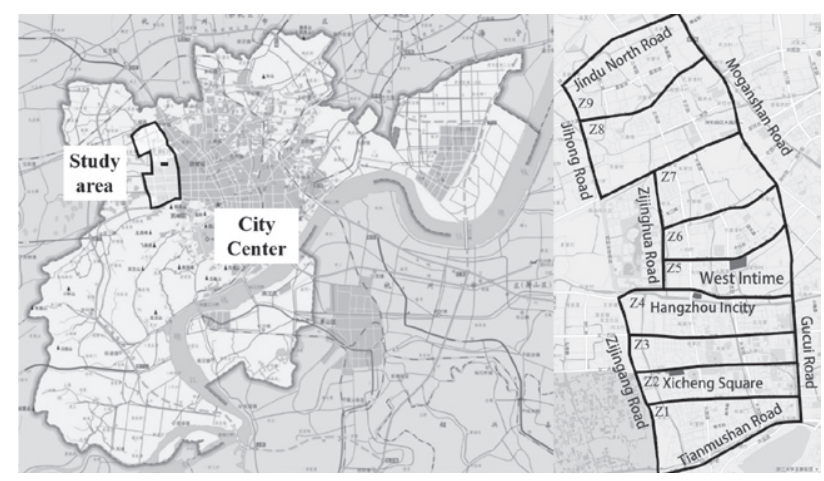

Figure 1. Regional distribution map transactions), so the partitions are denser and smaller. In contrast, the northern area lacks transaction volume, so the partitions are sparser and larger ${ }^{1}$. The sample size in each block changes from 555 (Zone 7) to 2,042 (Zone 1), and the north-south span ranges from $0.56 \mathrm{~km}$ (Zone 3 ) to $1.6 \mathrm{~km}$ (Zone 8 ). The regional distribution is shown in Figure 1.

\section{The model and its variables}

This study used hedonic price theory and the price gradient method to analyze the influence of the presence of a shopping mall. First, the hedonic price model was constructed and the influence degree of the mall on housing prices was captured by using the distance variables between the properties and the shopping mall. The distance is measured in Euclidean distances in common practice (Kholdy, Muhtaseb, \& Yu, 2014; Ding, 2004; Wen \& Tao, 2015). However, due to the uneven development of urban transport systems, Euclidean distances cannot represent the real accessibility of a region. Hence, some scholars (Ahlfeldt \& Wendland, 2008; Tse \& Chan, 2003) introduced commute costs to capture the price elasticity of variables while others (Söderberg \& Janssen, 2001; Coulson, 1991; Wen et al., 2014a) introduced azimuth dummy variables based on distance variables, which were used to capture the price gradients in different directions. There are also some studies using location dummy variables to characterize the price effects of objects on different blocks (Yiu \& Tam, 2004). The advantage of using location dummy variables is the assumption of a linear or logarithmic linear inverse relationship between housing prices and distances not being required. Hence, the effect of location differences can be more clearly captured within a small area in a city. Hence, the location dummy variables, as well as their interactions with year and period were introduced to construct an improved hedonic price model and expanded price gradient model to examine the housing price gradients from the dimensions of time and space. With the interactive dummy variables, we assumed that the price gradient varied over time and was impacted by the shopping mall.

1 To test the robustness of the study, we used another partition method with distance rings, as described in Appendix 1. 


\subsection{The simple hedonic price model}

The impact of shopping centers on housing prices can be characterized by the commuting costs. Setting the shopping mall as the object, we used a map of Gaode to measure the road distance from a property to the shopping mall. Then, we constructed the hedonic price model and introduced the dummy variable that characterize the time, as shown in Equation (1). The dependent variable, housing price, and continuous independent variables of $S, L$, and $N$ are often adopted in logarithmic form in the previous literature. We chose the form by comparison below.

$$
P=\alpha_{1}+\alpha_{2} S+\alpha_{3} L+\alpha_{4} N+\alpha_{5} D+\sum_{i=2}^{5} \beta_{i} Y_{i}+\varepsilon_{1},
$$

where: $P$ is the transaction price per $\mathrm{m}^{2}$ of a housing unit; $S$ is the structure characteristic variables, which include building's area, property's age, and number of floors; $L$ is the location characteristicariables, which include the distance between the city center and the properties, as well as the surrounding traffic convenience; $N$ is the neighborhood characteristic variables, which include the overall environment of the district and the education support measured by the surrounding schools, as well as sports and commercial facilities; $D$ is the distance to West Intime Shopping Mall using the road distance between the properties and the mall; $Y_{i}$ is the time dummy variable that equals 1 when the property is transacted at time $i$ (where $i=1, \ldots, 5$ in years) and 0 if otherwise; $\alpha_{1}$ represents the intercept, $\alpha_{2}$ to $\alpha_{4}$ capture the impacts of structure, location, and neighborhood characteristics, respectively, on housing prices, and $\alpha_{5}$ captures the impacts of the distance to the shopping mall.

\subsection{The improved hedonic price model}

The distance-based measures are inadequate representations of composite external effects as the influence of the mall on households will vary over space (Fik, Ling, \& Mulligan, 2003). To examine the housing price differences between zones, the improved hedonic price model was constructed by introducing the interaction term $Z_{i} Y_{j}$, as shown in Equation (2). The nine spatial divisions are adopted here. The price value of Zone 1 in 2011 is set as a reference point, so $Z_{1} Y_{1}$ does not enter the regression model. Housing prices change over time and the differences of the price indices between any two zones reflect the evolution of the price gradients.

$$
P=\eta_{1}+\eta_{2} S+\eta_{3} L+\eta_{4} N+\sum_{i=1}^{9} \sum_{j=1}^{5} \sigma_{i, j} Z_{i} Y_{j}+\varepsilon_{2},
$$

where: $P, S, L, N$, and $Y_{j}$ have the same definitions as before; $Z_{i}$ (where $i=1, \ldots, 9$ ) signifies the spatial dummy variables, which equal 1 when the property belongs to Zone $i$, and 0 if otherwise; $\eta_{k}$ (where $k=1,2,3,4$ ) and $\sigma_{i, j}$ are the coefficients to be estimated; $\varepsilon_{2}$ is the stochastic term. $\eta_{1}$ represents the intercept, and $\eta_{2}$ to $\eta_{4}$ capture the impacts of structure, location, and neighborhood char- acteristics, respectively, on housing prices. If the regression coefficient is positive, the characteristic is positively correlated with the price, and negative if otherwise. The coefficient $\sigma_{i, j}$ indicates the changing price in the year $j$ in Zone $i$ after controlling for the characteristic factors that affect the prices.

\subsection{The extended price gradient model}

The extended price gradient approach introduces the concept of the period to reflect the difference between the construction and operating phrases, which are based on the previous model, as shown in Equation (3).

$$
\begin{aligned}
& P=\phi_{1}+\phi_{2} S+\phi_{3} L+\phi_{4} N+\sum_{j=2}^{5} \gamma_{j} Y_{j}+\sum_{i=2}^{9} \lambda_{i} Z_{i}+ \\
& \sum_{i=2}^{9} \theta_{i, p} Z_{i} T_{2}+\varepsilon_{3},
\end{aligned}
$$

where: $P, S, L, N, Y_{j}$, and $Z_{i}$ have the same definitions as before; $T_{p}$ (where $p=1,2$; 1 means the construction period [2011.1-2013.8] while 2 means the operating period [2013.9-2015.12]) signifies the time dummy variables, which equal 1 when the property belongs to Period 1 , and 0 if otherwise; $\phi_{k}, \gamma_{j}, \lambda_{i}$, and $\theta_{i, p}$ (where $k=1,2,3,4$ ) are the coefficients to be estimated; $\varepsilon_{3}$ is the stochastic term.

As in Formula (3), $\phi_{1}$ denotes the intercept, and $\phi_{2}$ to $\phi_{4}$ capture the influence of each housing characteristic. The settings of the three dummy variables and the dummy interaction items is the innovative aspect of Formula (3) (Yiu \& Wong, 2005). (1) The price coefficient $\gamma_{j}$ is used to capture the common impacts on all zones in year $j$. Market fluctuations and policy changes are the main causes. Each $\gamma_{j}(j>1)$ corresponds to the base year $j=1$ (2011), so $\gamma_{1}$ is not included; (2) The azimuth coefficient $\lambda_{i}$ is used to capture the price change due to differences in locations between the 9 zones. When the base period is the construction period (Period 1), $\lambda_{i}$ can be interpreted as the price gradient of Period 1, which is based on $\lambda_{1}$ (Zone 1). The coefficients $\theta_{i, p}$ are used to estimate the zone-andperiod-specific variations in prices that are not captured by the year and location indices, which are affected by the different phrases of the shopping mall. Thus, the price gradient of $Z_{i}$ in period $\mathrm{p}$ can be measured by $\lambda_{i}+\theta_{i, p}$. Similarly, $Z_{1} T_{1}$ does not enter the regression model as a reference point.

\subsection{Variables and data}

The determinants of housing prices are mainly summarized as structure characteristics, location characteristics, and neighborhood characteristics, as shown in Table 3.

Structure characteristics are some of the characteristics of the property itself. The type of property and the different tectonic facilities can affect housing prices. In the study area, this study focuses on sub-high-rise and highrise house buildings, which are the main types of residential buildings in the Chinese housing market. So, the three 
most common factors that were selected are Size, Building's Age, and Floor/Level No. Size is positively related to the total price of a house, but the relationship with the price per $\mathrm{m}^{2}$ of the house is not certain. In many cases, the smaller the area, the higher is the unit price. Building's age is expected to be negative. In addition, housing prices are also influenced by the total number of floors in buildings because of the different levels of residential quality and comfort in sub-high-rise or high-rise buildings. Referring to Shi and Guo (2009), this paper introduces both Floor/Level No. and total number of floors into the model.

Location characteristics refer to the different locations of housing within a city. Different locations signify different environments and degrees of accessibility. Hangzhou has a particular geographical distribution. The traditional core areas include the CBD, i.e. Wulin Square and the scenic West Lake, which are very close to each other. In order to avoid multicollinearity, we included only the distance to $\mathrm{CBD}$ as the independent variable. The new emerging CBD, Qianjiang New City Area, currently has less influence than does Wulin Square and is located in the eastern part of the city far away from the study area, so it was not considered. The distance to the shopping mall was used to capture the mall's price gradient, which directly reflects the impact of the mall on housing prices. The surrounding bus route were measured by the number of bus lines within a radius of 1,000 meters around the houses, which is a comfortable walking distance limit. Bus route is supposed to have a positive effect on housing prices while Distance to CBD has a negative effect.

Neighborhood characteristics involve natural and cultural factors around the properties that can affect the housing prices. The environmental utility of the neighborhood is determined by many factors, including the natu-

Table 3. Descriptions residential characterization variables

\begin{tabular}{|c|c|c|}
\hline $\begin{array}{l}\text { Characterization } \\
\text { classification }\end{array}$ & Characterization variable & Quantitative basis \\
\hline \multirow{4}{*}{$\begin{array}{l}\text { Structure } \\
\text { characteristics }\end{array}$} & 1. Size & Area of housing construction $\left(\mathrm{m}^{2}\right)$ \\
\hline & 2. Building's age & Years (The age of a building built in 2015 is 1 year) \\
\hline & 3. Floor/Level No. & Level No. (the ground floor as the first floor) \\
\hline & 4. Total number of floors & Number of floors above ground level \\
\hline \multirow{2}{*}{$\begin{array}{l}\text { Location } \\
\text { characteristics }\end{array}$} & 5. Distance to CBD & Euclidean distance from the community to Wulin Square $(\mathrm{km})$ \\
\hline & 6. Bus route & Total number of bus routes within $1 \mathrm{~km}$ of the community \\
\hline \multirow{12}{*}{$\begin{array}{l}\text { Neighborhood } \\
\text { characteristics }\end{array}$} & 7. Distance to West Intime & Road distance from the community to West Intime $(\mathrm{km})$ \\
\hline & $\begin{array}{l}\text { 8. Distance to Hangzhou } \\
\text { Incity }\end{array}$ & Road distance from the community to Hangzhou Incity (km) \\
\hline & $\begin{array}{l}\text { 9. Distance to Xicheng } \\
\text { Square }\end{array}$ & Road distance from the community to Xicheng Square $(\mathrm{km})$ \\
\hline & 10. Inner environment & $\begin{array}{l}\text { Environment quality inside the community is divided into five degrees: quite } \\
\text { bad (scored 1), bad (scored 2), common (scored 3), good (scored 4), and very } \\
\text { good (scored 5) }\end{array}$ \\
\hline & 11. External environment & $\begin{array}{l}\text { Environment quality around the community is divided into five degrees: quite } \\
\text { bad (scored 1), bad (scored 2), common (scored 3), good (scored 4), and very } \\
\text { good (scored 5) }\end{array}$ \\
\hline & 12. Living facilities & $\begin{array}{l}\text { Supermarket, community store, bank, post office, and hospital within } 1,000 \mathrm{~m} \\
\text { of the community. Each item is scored } 1 \text { point (maximum possible total points } \\
\text { is 5) }\end{array}$ \\
\hline & 13. Sports facilities & $\begin{array}{l}\text { General quality of community sports facilities inside the community is divided } \\
\text { into five degrees: quite bad (scored 1), bad (scored 2), common (scored 3), good } \\
\text { (scored 4), and very good (scored 5) }\end{array}$ \\
\hline & 14. Property management & $\begin{array}{l}\text { Community property management service quality is divided into five degrees: } \\
\text { quite bad (scored 1), bad (scored 2), common (scored 3), good (scored 4), and } \\
\text { very good (scored 5) }\end{array}$ \\
\hline & $\begin{array}{l}\text { 15. Quality of primary } \\
\text { school }\end{array}$ & $\begin{array}{l}\text { Measures the quality of a primary school using a scoring method. The school } \\
\text { with the highest quality takes a score of } 4 \text { and that of the lowest quality takes a } \\
\text { score of } 1\end{array}$ \\
\hline & $\begin{array}{l}\text { 16. Quality of junior high } \\
\text { school }\end{array}$ & $\begin{array}{l}\text { Measures the quality of a junior high school using a scoring method. The school } \\
\text { with the highest quality takes a score of } 4 \text { and that of the lowest quality takes a } \\
\text { score of } 1\end{array}$ \\
\hline & $\begin{array}{l}\text { 17. Distance to primary } \\
\text { school }\end{array}$ & Euclidean distance from the community to nearest primary school $(\mathrm{km})$ \\
\hline & $\begin{array}{l}\text { 18. Distance to junior high } \\
\text { school }\end{array}$ & Euclidean distance from the community to nearest junior high school (km) \\
\hline
\end{tabular}


ral environment, living facilities, educational facilities, and sports facilities. In China, parents pay much attention to children's education. The school district significantly influences housing prices (Feng \& Lu, 2013; Wen, Y. Zhang, \& L. Zhang, 2014b), so this paper introduces the quality of schools and the distances to schools to characterize the impact of education and to measure school quality in the same way as did the research of Wen et al. (2014b) on Hangzhou. Commercial facilities also have a certain degree of impact on housing prices. Small commercial facilities can be considered together with living facilities due to their small influence while the impact of shopping malls is examined separately.

The sample data are the housing transaction prices from the beginning of 2011 to the end of 2015, which were obtained from a real estate agency in Hangzhou. Some relevant information, such as living facilities, sports facilities, and bus route, was not provided by the agency but obtained through a field survey conducted in 2010, 2012 and 2014. Our institute has conducted follow-up surveys on the residential buildings in Hangzhou every two to three years since 2008 to score the neighborhood and location characteristics of the community. A questionnaire has been designed to measure variables of interior environment, surrounding environment, sports facility, property management, quality of primary schools, and quality of junior high schools.

Mainly two aspects are considered in the choice of the research period. First, the real estate around West Intime developed later than that in the main city area. Although the average price of second-hand houses in the study area increased from 2008 to 2011, the housing transactions before 2011 of Zones 6, 7, 8 and 9 are absent, so the preconstruction period cannot form a price gradient contrast. Second, data on the marketing activities of the mall before construction are scarce. In addition, there was little advertising about West Intime before the construction. Therefore, we chose observations after 2011 for the sake of the equilibrium of sample spatial distribution. To ensure the quality and quantity of the data, we have adopted the price data of the second-hand houses rather than the newly-built houses. According to the statistical data, from 2011 to 2015 the transaction volume of newly-built houses was about 10,000 units in study area, which is very close to the volume of the second-hand houses. However, these newly-built units are concentrated in 16 communities and mostly distributed in the area north of Zone 6. There are few newly-built houses in Zones 1 to 5. The trading units of the second-hand houses are evenly distributed in 71 communities, which can better reflect the housing prices in the study area. To distinguish the changing impacts of the different stages, the data are divided into two periods: the construction period (P1: January 2011 - August 2013) and the operating period (P2: September 2013 - December 2015). The number of secondhand transactions in this area was 838 in 2011, which doubled in 2012 to 1,659 , and continued to grow to 1,943 in 2013. The increasing volume of second-hand transactions and the significant growth in the construction of newlybuilt houses north of West Intime reflect the signal effect of shopping malls on the housing market. The descriptive statistics of the variables are shown in Table 4.

Table 4. Descriptive statistics

\begin{tabular}{|c|c|c|c|c|c|c|c|c|}
\hline & \multicolumn{4}{|c|}{$\begin{array}{c}\text { Period 1 } \\
\text { (January } 2011-\text { August 2013, N = 3939) }\end{array}$} & \multicolumn{4}{|c|}{$\begin{array}{c}\text { Period 2 } \\
\text { (September 2013 - December 2015, N = 5315) }\end{array}$} \\
\hline & Min & Max & Mean & Std.dev. & Min & $\operatorname{Max}$ & Mean & Std.dev. \\
\hline Sale price $\left(¥ / \mathrm{m}^{2}\right)$ & 8228.00 & 37623.17 & 20374.56 & 4214.88 & 8203.45 & 40851.23 & 20195.14 & 4613.46 \\
\hline Size $\left(\mathrm{m}^{2}\right)$ & 23.82 & 264.60 & 90.09 & 31.105 & 23.71 & 330.98 & 94.79 & 31.259 \\
\hline Floor/Level No. & 1 & 27 & 6.21 & 5.103 & 1 & 27 & 6.44 & 5.136 \\
\hline Total floors & 4 & 29 & 11.56 & 7.445 & 4 & 29 & 12.14 & 7.516 \\
\hline Building's age (year) & 1 & 25 & 11.42 & 6.446 & 3 & 27 & 12.69 & 5.834 \\
\hline Distance to CBD (km) & 4.39 & 10.79 & 6.60 & 1.672 & 4.39 & 10.79 & 6.69 & 1.626 \\
\hline Bus route & 2 & 36 & 20.15 & 7.390 & 2 & 36 & 19.57 & 7.146 \\
\hline Distance to West Intime $(\mathrm{km})$ & 0.51 & 6.50 & 3.53 & 1.269 & 0.51 & 6.50 & 3.48 & 1.300 \\
\hline Distance to Hangzhou Incity $(\mathrm{km})$ & 0.46 & 7.40 & 3.00 & 1.346 & 0.46 & 7.40 & 2.96 & 1.277 \\
\hline Distance to Xicheng Square $(\mathrm{km})$ & 0.65 & 7.80 & 3.24 & 1.933 & 0.65 & 7.80 & 3.27 & 1.809 \\
\hline External environment & 1 & 5 & 3.14 & 0.670 & 1 & 5 & 3.24 & 0.666 \\
\hline Inner environment & 1 & 5 & 3.36 & 0.861 & 1 & 5 & 3.53 & 0.859 \\
\hline Living facilities & 1 & 5 & 4.05 & 1.251 & 1 & 5 & 3.96 & 1.240 \\
\hline Sports facilities & 1 & 5 & 2.66 & 1.081 & 1 & 5 & 2.81 & 1.092 \\
\hline Property management & 1 & 5 & 3.03 & 0.852 & 1 & 5 & 3.18 & 0.796 \\
\hline Quality of primary school & 1 & 3 & 2.02 & 0.847 & 1 & 3 & 1.98 & 0.862 \\
\hline Quality of junior high school & 1 & 2 & 1.69 & 0.462 & 1 & 2 & 1.64 & 0.480 \\
\hline Distance to primary school $(\mathrm{km})$ & 0.10 & 2.06 & 0.59 & 0.369 & 0.10 & 2.06 & 0.59 & 0.366 \\
\hline Distance to junior high school (km) & 0.19 & 3.28 & 1.42 & 0.838 & 0.19 & 3.28 & 1.45 & 0.841 \\
\hline
\end{tabular}




\section{Analysis of results}

The regression of the three models produced good results, which are discussed below.

\subsection{The results of simple hedonic price modelling approaches}

To estimate the impact of West Intime on the surrounding housing prices, we take advantage of the road distance to the mall to capture the price elasticity of the surrounding housing. The SPSS was used to estimate Equation (1) and analyze the housing characteristics. The results of the regression model are shown in Table 5.

Economic theory places few restrictions on the form of the hedonic price function (Hui et al., 2007; Feng \& Lu, 2013). By comparing the regression results of commonly adopted forms such as linear, semi-logarithmic (as shown in Table A2) and logarithmic, we found that logarithmic forms fit slightly better than the others. The correlation between independents was smaller and coefficient interpretation was more significant. The adjusted $R^{2}$ of Model
1 is 0.642 , which means that the independent variables could explain $64.2 \%$ of the dependent variable. Almost all the 21 variables are significant at the $1 \%$ level. To test for the spatial independence of the estimated error terms, referring to Fik et al. (2003), the residuals were regressed on the independent variables and location coordinates $x$, $y$ and their polynomial expression. The coefficient estimates of distance independent variables are all insignificant. While the location variable $x^{2}$ is significant in Model 1 , there is no significant location variable in Model 2 or Model 3, in which the spatial dummy variables are included (see Table 5). Due to the lack of location coordinates for housing units, and in order to solve the possible spatial correlation problem, we estimated the coordinates for house units by random calculations with GIS, based on the coordinates and shapes of the communities. Then, we conducted spatial econometric models using the constructed spatial weights as a robustness test. The results are shown in Appendix 2.

The effect of the structure characteristics all obtain the expected results. The coefficient of Total floors is

Table 5. Results of regression of the three models

\begin{tabular}{|c|c|c|c|c|c|c|}
\hline \multirow{2}{*}{ Independent variables } & \multicolumn{2}{|c|}{ Model 1} & \multicolumn{2}{|c|}{ Model 2} & \multicolumn{2}{|c|}{ Model 3} \\
\hline & Coefficient & $\mathrm{T}$ - statistics & Coefficient & $\mathrm{T}-$ statistics & Coefficient & $\mathrm{T}$ - statistics \\
\hline Constant & $10.431^{* * *}$ & 231.554 & $10.947^{* * *}$ & 140.912 & $10.961^{\star * *}$ & 141.590 \\
\hline Ln Size & $-0.093^{* * *}$ & -19.351 & $-0.112^{* * *}$ & -24.940 & $-0.115^{* * *}$ & -25.243 \\
\hline Ln Building's age & $0.017^{* * *}$ & 3.326 & $0.011^{* * *}$ & 5.166 & $0.012^{* * *}$ & 5.332 \\
\hline Ln Floor/Level No. & $0.010^{* * *}$ & 4.000 & $-0.073^{* * *}$ & -15.675 & $-0.074^{* * *}$ & -15.837 \\
\hline Ln. Total floors & $-0.033^{* *}$ & -7.127 & $-0.047^{* * *}$ & -8.464 & $-0.046^{* * *}$ & -8.473 \\
\hline Ln Distance to CBD & $-0.235^{* * *}$ & -17.770 & $-0.338^{* * *}$ & -11.650 & $-0.342^{* * *}$ & -11.665 \\
\hline Ln Distance to West Intime & $-0.109^{\star * \star}$ & -20.037 & I & I & I & I \\
\hline Ln Distance to Xicheng Square & $-0.048^{* * *}$ & -9.958 & $-0.039^{* * *}$ & -4.025 & $-0.039^{* * *}$ & -3.947 \\
\hline Bus route & $-0.002^{* * *}$ & -3.998 & $-0.004^{* * *}$ & -7.507 & $-0.003^{* * *}$ & -7.344 \\
\hline External environment & $0.048^{* * *}$ & 11.484 & $0.070^{* * *}$ & 15.541 & $0.069^{* * *}$ & 15.134 \\
\hline Inner environment & $-0.022^{* * *}$ & -6.345 & $-0.031^{* * *}$ & -7.815 & $-0.029^{* * *}$ & -7.247 \\
\hline Living facilities & $-0.007^{* * *}$ & -3.089 & $-0.031^{* * *}$ & -12.806 & $-0.031^{* * *}$ & -12.824 \\
\hline Sports facilities & $0.006^{* *}$ & 2.587 & $0.022^{* * *}$ & 9.695 & $0.022^{* * *}$ & 9.451 \\
\hline Property management & $0.084^{* * *}$ & 19.028 & $0.071^{* * *}$ & 16.670 & $0.072^{* * *}$ & 16.702 \\
\hline Quality of primary school & $0.084^{* * *}$ & 34.341 & $0.063^{* * *}$ & 21.108 & $0.063^{* * *}$ & 20.962 \\
\hline Quality of junior high school & $0.041^{* * *}$ & 5.725 & 0.005 & 0.386 & 0.005 & 0.340 \\
\hline Distance to primary school & $-0.032^{* * *}$ & -9.596 & $-0.028^{* * *}$ & -7.140 & $-0.028^{* * *}$ & -7.027 \\
\hline Distance to junior high school & $0.033^{* * \star}$ & 11.329 & $-0.047^{* * *}$ & -10.440 & $-0.046^{* * *}$ & -10.061 \\
\hline $\mathrm{Y} 2$ & $-0.071^{* * *}$ & -12.109 & 1 & 1 & $-0.059^{* * *}$ & -10.879 \\
\hline Y3 & -0.007 & -1.189 & I & 1 & 0.004 & 0.715 \\
\hline Y4 & $-0.055^{* * *}$ & -8.861 & 1 & 1 & $-0.057^{* * *}$ & -8.248 \\
\hline Y5 & $-0.059^{* * *}$ & -9.797 & 1 & 1 & $-0.054^{* * *}$ & -7.991 \\
\hline Adjusted $\mathrm{R}^{2}$ & \multicolumn{2}{|c|}{0.642} & \multicolumn{2}{|c|}{0.701} & \multicolumn{2}{|c|}{0.696} \\
\hline $\begin{array}{l}\text { Residuals regressed on location } \\
\text { variables }\end{array}$ & $\begin{array}{ll}x^{2} & -0.00 \\
x^{*} y & -0.00\end{array}$ & $\begin{array}{l}-111 \\
-1.515\end{array}$ & $\begin{array}{ll}x^{2} & 0.000 \\
x^{*} y & 0.000\end{array}$ & $\begin{array}{l}-1.085 \\
-1.272\end{array}$ & $\begin{array}{ll}x^{2} & 0.000 \\
x^{*} y & 0.000\end{array}$ & $\begin{array}{l}-0.952 \\
-1.147\end{array}$ \\
\hline
\end{tabular}

Notes: ${ }^{* *},{ }^{* *}$, and ${ }^{*}$ represent significance at the $1 \%, 5 \%$ and $10 \%$ levels, respectively. The dependent variable is $\ln P$. To test for the spatial independence of the estimated error terms, the residuals were regressed on the location variables, $\mathrm{x}, \mathrm{y}$ coordinate and $\mathrm{x}^{2}, \mathrm{y}^{2}, \mathrm{x}^{*} \mathrm{y}$. 
-0.033 , which is significant and negative. This result is consistent with the reality that sub-high-rise buildings with lower heights are more expensive due to less sharing of public areas and to more comfort. The coefficient of Distance to $C B D$ is -0.235 , which means that housing prices will decrease by $0.235 \%$ if the distance from a house to the city center increases by $1 \%$, indicating that Wulin Square definitely has much influence on the housing market. The quality of primary and junior high schools nearby can significantly increase housing prices and Distance to primary school has significant negative effect. Contrary to expectations, the coefficient of Bus route is negative, this phenomenon may be attributed to the fact that increasing the number of bus routes may produce negative effects, such as noise and environmental pollution (Wen, Xiao, \& Zhang, 2017). As for Neighborhood Characteristics, neither Inner environment nor Living facilities is as expected, which may be because the sample is concentrated in a limited area. The variables measured in the same way did not perform well either in housing submarket around the Grand Canal (Wen et al., 2017), but they were positively significant in house price regression with the sample of entire city (Wen et al., 2014a). We should improve the measure of these variables in future studies.

The distances to the shopping malls are the main research objects. West Intime and Hangzhou Incity are too close to each other, so there would be collinear problems if the two distance variables were both introduced into the model. Considering the smaller influence of Hangzhou Incity, Distance to Hangzhou Incity is not introduced into the model. The coefficients of Distance to West Intime and Distance to Xicheng Square are both significant and negative as were expected, but Distance to West Intime is a little larger with a value of -0.109 . In the case of excluding the impacts of other characteristic variables, as the road distance to West Intime increases $1 \%$, housing prices decrease by $0.109 \%$. The result indicates that for the study area, West Intime has a significant impact on housing prices and is more influential than Xicheng Square. In this model, the influence of West Intime on housing prices is characterized initially and roughly. The following two models provide further analysis.

\subsection{The results of improved hedonic price modeling approaches}

Similarly, the least-square method was used to estimate Model 2. The adjusted $R^{2}$ increases to 0.701 , indicating that compared to Model 1, this model is more explanatory. Almost all the characteristic variables are significant at the $1 \%$ level. The coefficient of Distance to Xicheng Square is also significant and similar to the result of Model 1. By controlling the influence of Xicheng Square, the impact of West Intime on housing prices can be captured by spatiotemporal interactions, whose coefficients are shown in Table 6. There are 44 spatio-temporal interaction coefficients, of which 39 are significant.

In the space dimension, the housing price indices of the five zones in the southwestern region (Zones 1-5) are relatively higher than the four zones in the northwestern region (Zones 6-9).

With the purpose of observing the influence of West Intime on the different zones in more detail, we further calculated the price gradients among the various zones and observed the changes. This helped to analyze the temporal and spatial influences of West Intime. Zone 1 is the farthest south, and so, is farthest away from West Intime and closest to the city center. The impact received from West Intime is relatively minimal. Therefore, Zone 1 was set as the reference area and the price indices of the other zones were subtracted from the price gradient of each zone. For each zone, the price gradient of Zone $i$ $(i=2, \ldots, 9)$ is equal to the difference between the price indices of Zone $i$ and Zone 1. The results are shown in Figures 2 and 3.

Figure 2 shows the price gradients for Zones $2-5$ based on Zone 1. The results of 2011-2013 represent the price gradients of Period One while the results of 2014-2015 represent Period Two. The results are summarized as follows:

1) In Period One, the price gradients of the four zones were basically stabilized with few changes. Even in 2012, which was the peak of the construction period, the price gradient of Zone 5 was reduced by 0.027 . The noise generated by the project construction might have had a negative impact on housing prices (Henneberry, 1998).

Table 6. The value of the coefficient $\sigma_{i, j}($ Model 2)

\begin{tabular}{|c|c|c|c|c|c|c|c|c|c|}
\hline & $\mathrm{Z} 1$ & $\mathrm{Z} 2$ & $\mathrm{Z} 3$ & $\mathrm{Z} 4$ & $\mathrm{Z} 5$ & $\mathrm{Z} 6$ & $\mathrm{Z} 7$ & $\mathrm{Z} 8$ & $\mathrm{Z} 9$ \\
\hline $\mathrm{Y} 1$ & $/$ & $0.042^{* * *}$ & $0.121^{* * *}$ & $0.167^{* * *}$ & $0.121^{* * *}$ & $-0.108^{* * *}$ & -0.039 & $0.105^{* * *}$ & $-0.082^{* * *}$ \\
\hline $\mathrm{Y} 2$ & $-0.043^{* * *}$ & 0.002 & $0.069^{* * *}$ & $0.126^{* * *}$ & $0.051^{* *}$ & $-0.209^{* * *}$ & $-0.197^{* * *}$ & 0.025 & $-0.148^{* * *}$ \\
\hline $\mathrm{Y} 3$ & 0.009 & $0.078^{* * *}$ & $0.125^{* * *}$ & $0.200^{* * *}$ & $0.126^{* * *}$ & $-0.132^{* * *}$ & $-0.103^{* * *}$ & $0.068^{* *}$ & $-0.063^{* *}$ \\
\hline $\mathrm{Y} 4$ & $-0.048^{* * *}$ & $0.027^{* *}$ & $0.099^{* * *}$ & $0.164^{* * *}$ & $0.145^{* * *}$ & $-0.141^{* * *}$ & $-0.131^{* * *}$ & $-0.058^{* *}$ & $-0.070^{* *}$ \\
\hline $\mathrm{Y} 5$ & $-0.071^{* * *}$ & 0.006 & $0.119^{* * *}$ & $0.159^{* * *}$ & $0.217^{* * *}$ & $-0.083^{* * *}$ & $-0.127^{* * *}$ & $-0.071^{* * *}$ & $-0.069^{* *}$ \\
\hline
\end{tabular}

Note: ${ }^{* *},{ }^{* *}$, and ${ }^{\star}$ represent significance at the $1 \%, 5 \%$ and $10 \%$ levels, respectively. 


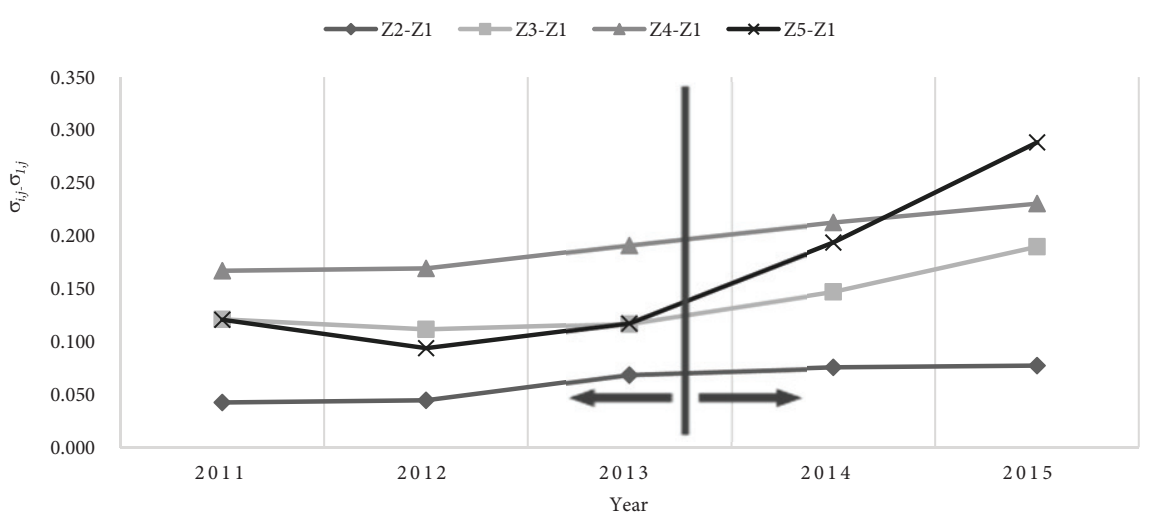

Figure 2. Price gradients of Zones 2-5 based on Zone 1

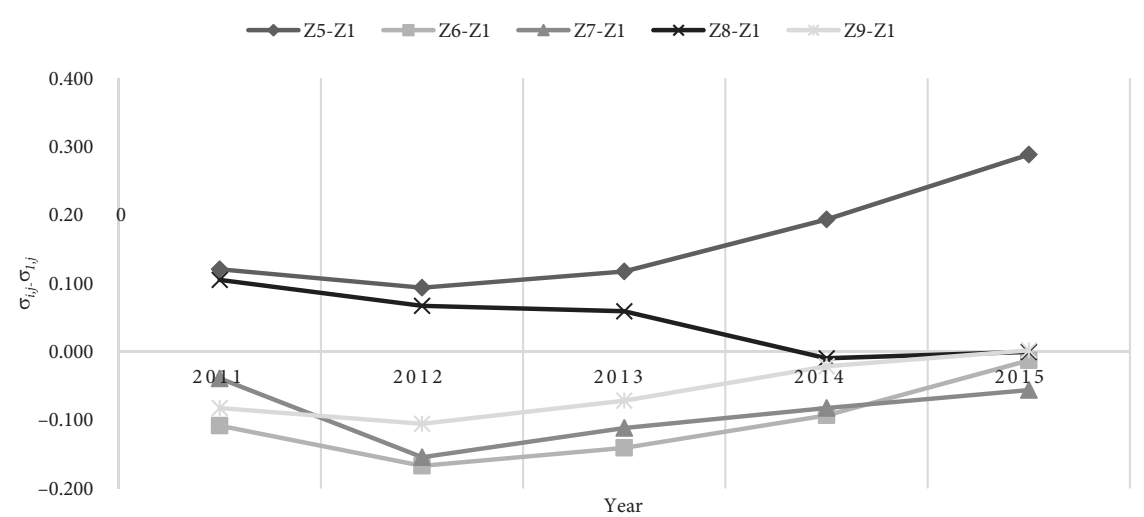

Figure 3. Price gradients of Zones 6-9 based on Zone 1

Note: As a reference, the price gradient for Zone 5 is also shown.

2) In Period Two, the price growth rate of Zone 5 was very significant. Zones 3 and 4, which were slightly farther away, were also affected by the positive effect of the shopping mall, leading to the increase in the price gradients based on Zone 1 . The price gradient of Zone 2 increased slightly compared with the price gradients of the other zones. The results show that a significant effect on the residential prices in the south area after the open of the mall and the "value-added" range decreased with the distance.

Zones 6-9 are located away from the city center and West Intime is the only large-scale commercial facility in the surrounding area. So, theoretically, these four zones are better able to reflect the spatio-temporal impact of West Intime on the surrounding housing prices. Figure 3 shows the price gradients of the four zones based on Zone 1:

1) In Period One, the price gradients of the four zones fluctuated less. Zones 6 and 7 had a certain degree of price decline in 2012 and rebounding in 2013, largely due to the impact of the neighboring construction.

2) In Period Two, the price gradient of Zone 6 increased significantly and the value was near zero in
2015, showing that the price of Zone 6 had begun to catch up with Zone 1. Similarly to Zone 6, the price gradient of Zone 7 also showed a clear upward trend with a smaller rise. The changes in the price gradient of Zone 8 was confusing while there were still some visible positive changes in Zone 9.

In this model, the value-added effect can be clearly seen, especially in Zones 6-9, and the influence decreases from Zone 5 to the other zones on both sides, but this method of price gradient calculation still could not eliminate the time fixed effect completely.

\subsection{The results of extended price gradient approaches}

The explanatory power of Model 3 is $69.6 \%$, which is very close to that of Model 2. The confidence levels of the characteristic variables are almost the same as before. Only one spatial-temporal interaction coefficient $\theta$ was not significant. Therefore, the model can explain the existing data well. Then, the price gradient was calculated by $\lambda_{i}+\theta_{i, p}$. The results are shown in Table 7. 
Table 7. The value of $\lambda_{i}+\theta_{i, p}($ Model 3)

\begin{tabular}{|c|c|c|c|c|c|c|c|c|c|}
\hline & $\mathrm{Z} 1$ & $\mathrm{Z} 2$ & $\mathrm{Z} 3$ & $\mathrm{Z} 4$ & $\mathrm{Z} 5$ & Z6 & $\mathrm{Z7}$ & $\mathrm{Z} 8$ & $\mathrm{Z9}$ \\
\hline$\lambda_{i}$ & I & $0.063^{\star * *}$ & $0.120^{\star * *}$ & $0.183^{\star * *}$ & $0.112^{* * *}$ & $-0.137^{\star * *}$ & $-0.105^{\star * *}$ & $0.087^{\star * *}$ & $-0.078^{\star * *}$ \\
\hline$\theta_{i, p}$ & 1 & 0.006 & $0.043^{\star * *}$ & $0.031^{\star * *}$ & $0.127^{\star * *}$ & $0.090^{* * *}$ & $0.029^{* * *}$ & $-0.093^{\star * *}$ & $0.057^{\star * *}$ \\
\hline$T 1\left(\lambda_{i}+\theta_{i, p}\right)$ & 0.000 & 0.063 & 0.120 & 0.183 & 0.112 & -0.137 & -0.105 & 0.087 & -0.078 \\
\hline$T 2\left(\lambda_{i}+\theta_{i, p}\right)$ & 0.000 & 0.068 & 0.164 & 0.214 & 0.239 & -0.047 & -0.076 & -0.005 & -0.022 \\
\hline
\end{tabular}

Note: ${ }^{* * *},{ }^{* *}$, and ${ }^{*}$ represent significance at the $1 \%, 5 \%$ and $10 \%$ levels, respectively.

Figure 4 exhibits the price gradients of nine zones in two periods. Zone 1 is still set as the benchmark. In the premise of eliminating the time fixed effect and assuming that the housing prices in Zone 1 had not changed during the construction and operating periods, the price gradients of the other zones were obtained based on Zone 1.

Compared to the previous two methods, this treatment was better able to remove the influence of other factors on the time dimension. The findings are as follows:

1) The price gradients of Period 2 are shown to be significantly higher than those of Period 1 (except for Zone 8). In the area south of West Intime (from $\mathrm{Z} 2-\mathrm{Z5}$ ), the price gradient differences between the two periods are $0.006,0.043,0.031$, and 0.127 , respectively. Z3 and Z4 almost have the same value added effect caused by West Intime while Z2 has the smallest appreciation. Zone 5 has become the new peak in housing prices and the price increases $13.5 \%$ in Period 2. The value-added effect can be found to decrease with distance, but it is not a completely linear relationship.

2) In the north area of West Intime (from Z6-Z9), the price gradient differences between the two periods are $0.090,0.029,-0.093$, and 0.057 , respectively. Generally the price gradient difference between the two periods in each zone is negatively correlated with the distance from West Intime. The price gradient difference of Zone 6 is the largest while Zone 7 is the smallest except the negative appreciation in Zone 8 . The time fixed effect has largely been eliminated, so the price gradient difference is caused by the influence of West Intime.
The above three models can be good proof that West Intime has had a positive impact on the surrounding housing prices. Model 1 identifies the impact of West Intime on housing prices as being inversely proportional to the distance. The two price gradient models allow insight into the spatial price trend of West Intime's surrounding area. We found that the impacts on the surrounding housing prices in Zones 5 and 6 were the largest. In contrast, the impacts on Zones 2 and 8 were relatively weak. In terms of time, examining the housing prices in the two periods shows that the increase in housing prices during the operating period was very large while during the construction period, housing prices changed little and even appeared to have experienced a certain degree of negative effects.

\section{Conclusions}

Using the price gradient method and hedonic price theory, this study analyzed the influence of a shopping mall on the surrounding housing prices in terms of time and space. First, the results of the hedonic model show that West Intime has a significant impact on housing prices, which decays with distance. Then, in the price gradient method, location and time dummy variables were introduced to capture changes in housing prices at different times in various locations. The results indicate that almost all the zones in the study area have had their prices influenced to some extent if there was a shopping mall nearby. Especially in the zones closely surrounding the mall, housing prices had obviously increased by more than 10 percent upon the mall's opening. The spatial and temporal interaction terms used in Model 2 and Model 3 can

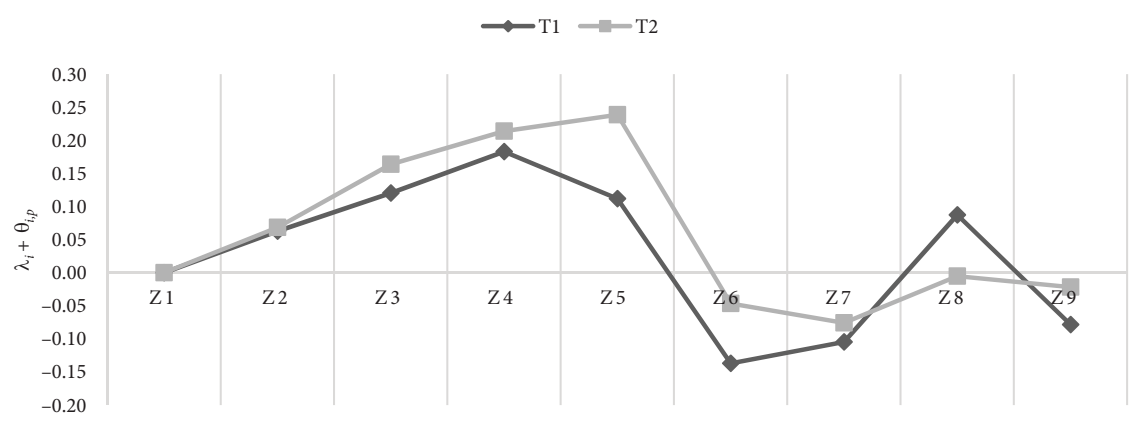

Figure 4. Price gradients of Zones 1-9 
effectively separate the impact of the shopping mall on the surrounding house prices during the construction and operation phases. Through the block division based on the main roads, we can clearly observe the reaction of residential groups at different locations relative to the shopping mall, which is rarely discussed in the previous literature.

To the best of our knowledge, this paper is one of the few studies concerning the impacts of a shopping mall at different periods of time. Before the completion of the construction, the expected effect of West Intime is very small. The surrounding housing prices were subject to minimal influence, which is different from the expectation effect found in some subway or transportation studies. The reason may be that the influence of a shopping mall largely depends on its own anchor tenants and operational capacity. Before the completion of the construction of West Intime, people knew little about the mall, because it had not been promoted much. Therefore, there was no obvious influence on the housing price. Nevertheless, during the construction of the mall, the transaction of second-hand houses and the construction of new houses in the affected area increased significantly, showing the signal effect of the shopping mall. Upon completion in Period 2, the mall's good operating conditions and reputation greatly enhanced its radiative influence in the area.

This paper provides some implications for city planners and governments. The model has evaluated the range of a mall's influence on housing prices and offers a good reference for avoiding the imbalanced distribution of shopping malls in different districts and the scarcity of retail shops. Meanwhile, the effects of shopping malls on housing prices can be taken into consideration for land use planning by the government. Due to the vital influence of shopping malls on the surrounding housing prices, the introduction of malls and commercial facilities is a good practice to leading the development of a new city area.

The limitations of this study include the short span of the data. We cannot study the impact of the shopping mall on housing prices before construction. Therefore, it is impossible to explore if the shopping mall had had an effect before its construction. The data only covers the two years after the opening of the mall, so we cannot observe changes in housing prices for any longer term. Nevertheless, due to the brand effect and good management, the mall performed well and entered a stable operating period during the first two years. Further research is needed to explore how the impact pattern differs at different scales and operational levels of shopping malls, and to observe the interaction effect of two or more shopping malls on housing market.

\section{Acknowledgements}

The authors would like to thank the editor and the anonymous reviewers for the positive and constructive comments and suggestions.

\section{Funding}

This work was supported by the China Scholarship Council under Grant No. 201706325013; and Zhejiang Provincial Natural Science Foundation of China under Grant No. LY18G030002.

\section{References}

Ahlfeldt, G. M., \& Wendland, N. (2011). Fifty years of urban accessibility: the impact of the urban railway network on the land gradient in Berlin 1890-1936. Regional Science and Urban Economics, 41(2), 77-88.

https://doi.org/10.1016/j.regsciurbeco.2010.10.001

Alonso, W. (1964). Location and land use: toward a general theory of land rent. Cambridge: Harvard University Press. https://doi.org/10.4159/harvard.9780674730854

Berry, B. J., \& Garrison, W. L. (1958). Recent developments of central place theory. Papers in Regional Science, 4(1), 107-120. https://doi.org/10.1111/j.1435-5597.1958.tb01625.x

Brueckner, J. K. (1993). Inter-store externalities and space allocation in shopping centers. The Journal of Real Estate Finance and Economics, 7(1), 5-16.

https://doi.org/10.1007/BF01096932

Carter, C. (2009). Review articles: what we know about shopping centers. Journal of Real Estate Literature, 17(2), 163-180.

Carter, C. C., \& Haloupek, W. J. (2002). Dispersion of stores of the same type in shopping malls: theory and preliminary evidence. Journal of Property Research, 19(4), 291-311. https://doi.org/10.1080/0959991022000013550

Chau, K. W., \& Chin, T. L. (2003). A critical review of literature on the hedonic price model. International Journal for Housing Science and Its Applications, 27(2), 145-165.

Chau, K. W., \& Ng, F. F. (1998). The effects of improvement in public transportation capacity on residential price gradient in Hong Kong. Journal of Property Valuation and Investment, 16(4), 397-410. https://doi.org/10.1108/14635789810228204

Christaller, W. (1933). Die zentralen Orte in Süddeutschland: eine ökonomisch-geographische Untersuchung über die Gesetzmässigkeit der Verbreitung und Entwicklung der Siedlungen mit städtischen Funktionen. University Microfilms.

Clark, D. E., \& Herrin, W. E. (2000). The impact of public school attributes on home sale prices in California. Growth and Change, 31(3), 385-407. https://doi.org/10.1111/0017-4815.00134

Clark, W. A. (1968). Consumer travel patterns and the concept of range 1. Annals of the Association of American Geographers, 58(2), 386-396.

https://doi.org/10.1111/j.1467-8306.1968.tb00651.x

Colwell, P. F., Gujral, S. S., \& Coley, C. (1985). The impact of a shopping center on the value of surrounding properties. Real Estate Issues, 10(1), 35-39.

Coulson, N. E. (1991). Really useful tests of the monocentric model. Land Economics, 67(3), 299-307. https://doi.org/10.2307/3146425

De Palma, A., Ginsburgh, V., Papageorgiou, Y. Y., \& Thisse, J. F. (1985). The principle of minimum differentiation holds under sufficient heterogeneity. Econometrica: Journal of the Econometric Society, 767-781. https://doi.org/10.2307/1912653

Des Rosiers, F., Lagana, A., Thériault, M., \& Beaudoin, M. (1996). Shopping centres and house values: an empirical investigation. Journal of Property Valuation and Investment, 14(4), 41-62. https://doi.org/10.1108/14635789610153461 
Ding, C. (2004). Urban spatial development in the land policy reform era: evidence from Beijing. Urban Studies, 41(10), 1889-1907. https://doi.org/10.1080/0042098042000256305

Erkip, F. (2005). The rise of the shopping mall in Turkey: the use and appeal of a mall in Ankara. Cities, 22(2), 89-108. https://doi.org/10.1016/j.cities.2004.10.001

Fasli, M., Riza, M., \& Erbilen, M. (2016). The assessment and impact of shopping centers: case study lemar. Open House International, 41(4), 98-103.

Feng, H., \& Lu, M. (2013). School quality and housing prices: empirical evidence from a natural experiment in Shanghai, China. Journal of Housing Economics, 22(4), 291-307. https://doi.org/10.1016/j.jhe.2013.10.003

Fik, T. J., Ling, D. C., \& Mulligan, G. F. (2003). Modeling spatial variation in housing prices: a variable interaction approach. Real Estate Economics, 31(4), 623-646. https://doi.org/10.1046/j.1080-8620.2003.00079.x

Freeman, A. M. (1981). Hedonic prices, property values and measuring environmental benefits: a survey of the issues. In Measurement in public choice (pp. 13-32). London: Palgrave Macmillan. https://doi.org/10.1007/978-1-349-05090-1_2

Gatzlaff, D. H., \& Ling, D. C. (1994). Measuring changes in local house prices: an empirical investigation of alternative methodologies. Journal of Urban Economics, 35(2), 221-244. https://doi.org/10.1006/juec.1994.1014

Golledge, R. G., Rushton, G., \& Clark, W. A. (1966). Some spatial characteristics of Iowa's dispersed farm population and their implications for the grouping of central place functions. Economic Geography, 42(3), 261-272. https://doi.org/10.1080/00130095.1966.11729852

Gu, J., \& Jia, S. H. (2008). The effects of expected transport improvements on housing prices and price spatial distribution-hangzhou-based research evidence of planning the mass transit railway. Economic Geography, 6, 1020-1024.

Henneberry, J. (1998). Transport investment and house prices. Journal of Property Valuation and Investment, 16(2), 144158. https://doi.org/10.1108/14635789810212913

Hotelling, H. (1929). Stability in competition. Economic Journal, 39(153), 41-57. https://doi.org/10.2307/2224214

Hui, E. C., Chau, C. K., Pun, L., \& Law, M. Y. (2007). Measuring the neighboring and environmental effects on residential property value: using spatial weighting matrix. Building and Environment, 42(6), 2333-2343.

https://doi.org/10.1016/j.buildenv.2006.05.004

Kholdy, S., Muhtaseb, M., \& Yu, W. (2014). Effect of an open air, mixed - use shopping center on the price of nearby residential properties. Journal of Real Estate Practice and Education, 17(1), 1-18.

Larsen, V., Shelton, R., \& Wright, N. D. (2015). Shopping center attitudes: an empirical test of predictive attributes. Academy of Marketing Studies Journal, 19(2), 1-93.

Loomis, J., Santiago, L., \& Lopez de Jesus, Y. (2012). Effects of construction and operation phases on residential property prices of the Caribbean's first modern rail transit system. Urban Public Economics Review, 17, 56-77.

McMillan, D., Jarmin, R., \& Thorsnes, P. (1992). Selection bias and land development in the monocentric model. Journal of Urban Economics, 31, 273-284.

https://doi.org/10.1016/0094-1190(92)90056-Q

McMillen, D. P., \& McDonald, J. (2004). Reaction of house prices to a new rapid transit line: Chicago's midway line, 1983-1999. Real Estate Economics, 32(3), 463-486. https://doi.org/10.1111/j.1080-8620.2004.00099.x
Mejia, L., \& Benjamin, J. (2002). What do we know about the determinants of shopping center sales? Spatial vs. non-spatial factors. Journal of Real Estate Literature, 10(1), 1-26.

Mok, H. M., Chan, P. P., \& Cho, Y. S. (1995). A hedonic price model for private properties in Hong Kong. The Journal of Real Estate Finance and Economics, 10(1), 37-48. https://doi.org/10.1007/BF01099610

Ooi, J. T., \& Sim, L. L. (2007). The magnetism of suburban shopping centers: do size and Cineplex matter? Journal of Property Investment \& Finance, 25(2), 111-135. https://doi.org/10.1108/14635780710733816

Ozuduru, B. H. (2013). Assessment of spatial dependence using spatial autoregression models: empirical analysis of shopping center space supply in Ohio. Journal of Urban Planning and Development, 139(1), 12-21.

https://doi.org/10.1061/(ASCE)UP.1943-5444.0000129

Rushton, G. (1969). Analysis of spatial behavior by revealed space preference. Annals of the Association of American Geographers, 59(2), 391-400.

https://doi.org/10.1111/j.1467-8306.1969.tb00678.x

Sedgley, N. H., Williams, N. A., \& Derrick, F. W. (2008). The effect of educational test scores on house prices in a model with spatial dependence. Journal of Housing Economics, 17(2), 191-200. https://doi.org/10.1016/j.jhe.2007.12.003

Shi, Y. S., \& Guo, H. N. (2009). Temporal-spatial impacts of the Shanghai South Railway Station on housing prices. Acta Geographica Sinica, 2(007).

Sirmans, C., \& Guidry, K. (1993). The determinants of shopping center rents. Journal of Real Estate Research, 8(1), 107-115.

Sirpal, R. (1994). Empirical modeling of the relative impacts of various sizes of shopping centers on the values of surrounding residential properties. Journal of Real Estate Research, 9(4), 487-505.

Söderberg, B., \& Janssen, C. (2001). Estimating distance gradients for apartment properties. Urban Studies, 38(1), 61-79. https://doi.org/10.1080/00420980123880

So, H. M., Tse, R. Y., \& Ganesan, S. (1997). Estimating the influence of transport on house prices: evidence from Hong Kong. Journal of Property Valuation and Investment, 15(1), 40-47. https://doi.org/10.1108/14635789710163793

Song, Y., \& Sohn, J. (2007). Valuing spatial accessibility to retailing: a case study of the single family housing market in Hillsboro, Oregon. Journal of Retailing and Consumer Services, 14(4), 279-288.

https://doi.org/10.1016/j.jretconser.2006.07.002

Tse, C. Y., \& Chan, A. W. (2003). Estimating the commuting cost and commuting time property price gradients. Regional Science and Urban Economics, 33(6), 745-767. https://doi.org/10.1016/S0166-0462(03)00011-5

Weigher, J. C., \& Zerbst, R. H. (1973). The externalities of neighborhood parks: an empirical investigation. Land Economics, 49(1), 99-105. https://doi.org/10.2307/3145337

Wen, H., Bu, X., \& Qin, Z. (2014a). Spatial effect of lake landscape on housing price: a case study of the West Lake in Hangzhou, China. Habitat International, 44, 31-40. https://doi.org/10.1016/j.habitatint.2014.05.001

Wen, H., \& Tao, Y. (2015). Polycentric urban structure and housing price in the transitional China: evidence from Hangzhou. Habitat International, 46, 138-146. https://doi.org/10.1016/j.habitatint.2014.11.006

Wen, H., Xiao, Y., \& Zhang, L. (2017). Spatial effect of river landscape on housing price: an empirical study on the Grand Canal in Hangzhou, China. Habitat International, 63, 34-44. https://doi.org/10.1016/j.habitatint.2017.03.007 
Wen, H., Zhang, Y., \& Zhang, L. (2014b). Do educational facilities affect housing price? An empirical study in Hangzhou, China. Habitat International, 42, 155-163.

https://doi.org/10.1016/j.habitatint.2013.12.004

Yiu, C., \& Tam, C. (2004). A review of recent empirical studies on property price gradients. Journal of Real Estate Literature, 12(3), 305-322.

\section{Appendix 1}

With the purpose of testing the robustness of the empirical results, this study used the traditional partitioning method with distance rings to verify whether the results are consistent. The study area was divided into eight zones $(0-1 \mathrm{~km}, 1-1.5 \mathrm{~km}, 1.5-2 \mathrm{~km}, 2-2.5 \mathrm{~km}, 2.5-3 \mathrm{~km}$, $3-3.5 \mathrm{~km}, 3.5-4 \mathrm{~km}$, and $4-5 \mathrm{~km})$ according to their distance to West Intime, as shown in Figure A1. Owing to the lack of communities, Zones 1 and 8 span $1 \mathrm{~km}$ while other zones span $0.5 \mathrm{~km}$. In the east, we set a boundary line along Xueyuan Road, which is located in the middle line of West Intime and the CBD. The area to the east is closer to the city center.

The three models were applied again. The results are shown in Table A1. The three models all behave well and the adjusted $R^{2}$ are above 0.55 . Almost all independent
Yiu, C. Y., \& Wong, S. K. (2005). The effects of expected transport improvements on housing prices. Urban Studies, 42(1), 113-125. https://doi.org/10.1080/0042098042000309720

Yu, T. H., Cho, S. H., \& Kim, S. G. (2012). Assessing the residential property tax revenue impact of a shopping center. The Journal of Real Estate Finance and Economics, 45(3), 604-621. https://doi.org/10.1007/s11146-010-9292-X

Table A1. Results of regression of the three models

\begin{tabular}{|c|c|c|c|c|c|c|}
\hline \multirow{2}{*}{ Independent variables } & \multicolumn{2}{|c|}{ Model 1} & \multicolumn{2}{|c|}{ Model 2} & \multicolumn{2}{|c|}{ Model 3} \\
\hline & Coefficient & $\mathrm{T}-$ statistics & Coefficient & Coefficient & $\mathrm{T}-$ statistics & Coefficient \\
\hline Constant & $10.718^{\star * *}$ & 270.712 & $11.123^{\star * *}$ & 233.887 & $11.177^{\star * *}$ & 244.944 \\
\hline Ln Size & $-0.090^{* * *}$ & -21.711 & $-0.085^{\star * *}$ & -20.923 & $-0.085^{\star * *}$ & -20.976 \\
\hline Ln Floor/Level No. & $-0.033^{\star * *}$ & -8.278 & $-0.036^{\star * *}$ & -9.047 & $-0.036^{\star \star *}$ & -9.120 \\
\hline Ln Total floors & $0.009^{* * *}$ & 3.961 & $0.009^{* * *}$ & 4.567 & $0.010^{* * *}$ & 4.599 \\
\hline Ln Building's age & -0.001 & -1.162 & $-0.003^{* * *}$ & -3.579 & $-0.004^{\star * *}$ & -4.426 \\
\hline Ln Distance to CBD & $-0.431^{* * *}$ & -39.491 & $-0.538^{\star * *}$ & -46.694 & $-0.542^{\star * *}$ & -46.896 \\
\hline Ln Distance to West Intime & $-0.053^{* * *}$ & -15.442 & & & & \\
\hline Ln Distance to Xicheng Square & $-0.016^{* * *}$ & -4.077 & $-0.036^{\star * *}$ & -7.412 & $-0.038^{* * *}$ & -7.848 \\
\hline Bus route & $-0.003^{* * *}$ & -9.935 & $-0.004^{* * *}$ & -14.169 & $-0.004^{\star * *}$ & -14.187 \\
\hline Surrounding environment & $0.090^{* * *}$ & 25.051 & $0.051^{\star * *}$ & 12.635 & $0.051^{\star * *}$ & 12.472 \\
\hline Inner environment & $-0.019^{* * *}$ & -6.597 & -0.003 & -1.110 & -0.003 & -1.160 \\
\hline Living facilities & $-0.006^{\star *}$ & -2.113 & 0.004 & 1.347 & 0.003 & 1.120 \\
\hline Sports facilities & $0.035^{\star * *}$ & 17.221 & $0.031^{\star * *}$ & 15.402 & $0.030^{\star * *}$ & 15.225 \\
\hline Property management & $0.063^{* * *}$ & 22.996 & $0.061^{\star * *}$ & 22.294 & $0.062^{\star * *}$ & 22.615 \\
\hline Quality of primary school & $0.054^{* * *}$ & 25.602 & $0.059^{* * *}$ & 25.861 & $0.059^{* * *}$ & 25.830 \\
\hline Quality of junior high school & 0.003 & 0.513 & -0.009 & -1.262 & -0.014 & -1.872 \\
\hline Ln Distance to primary school & $-0.005^{\star *}$ & -2.339 & $0.009^{* * *}$ & 4.219 & $0.009^{* * *}$ & 4.206 \\
\hline Ln Distance to junior high school & $0.038^{* * *}$ & 16.232 & -0.002 & -0.812 & -0.002 & -0.738 \\
\hline Y2 & $-0.063^{\star * *}$ & -12.570 & 1 & 1 & $-0.062^{\star \star \star}$ & -13.046 \\
\hline Y3 & 0.008 & 1.579 & 1 & I & 0.011 & 2.386 \\
\hline Y4 & $-0.039^{* * *}$ & -7.633 & l & I & $-0.023^{\star * *}$ & -3.310 \\
\hline Y5 & $-0.048^{\star * *}$ & -10.295 & l & l & $-0.031^{\star * *}$ & -4.675 \\
\hline Adjusted $\mathrm{R}^{2}$ & \multicolumn{2}{|c|}{0.557} & \multicolumn{2}{|c|}{0.596} & \multicolumn{2}{|c|}{0.592} \\
\hline
\end{tabular}

Note: ${ }^{* *},{ }^{* *}$, and ${ }^{*}$ represent significance at the $1 \%, 5 \%$ and $10 \%$ levels, respectively. 


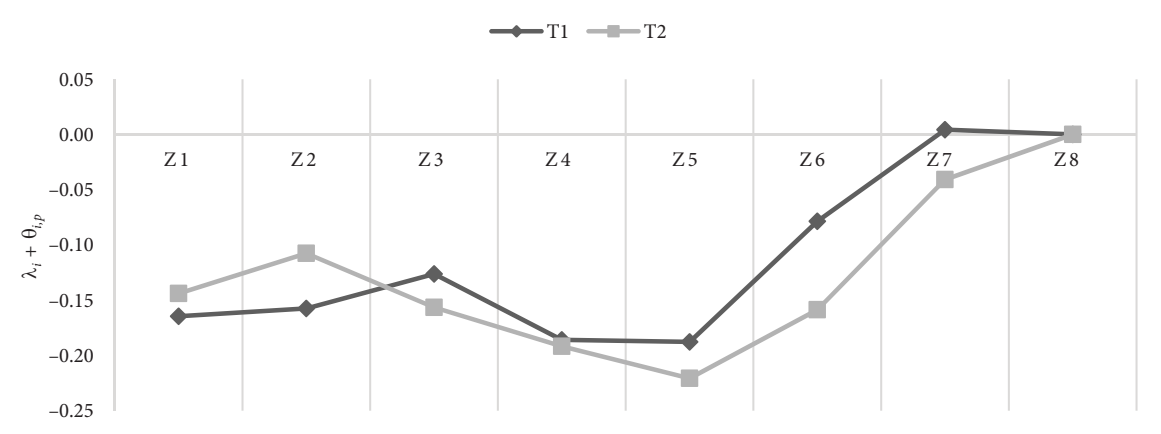

Figure A2. Price gradients of Zones 1-8

variables are significant and the values of the coefficients are hardly different from the original partitioning method.

In Model 1, the coefficient of Distance to West Intime is -0.053 , which shows the negative price gradient and validates the influence of West Intime. In Model 2, house prices in Zones 1 and 2 increased after 2014, while those in other zones declined over two years, excepting for Zone $8^{2}$. In Model 3, as shown in Figure A2, there was a clear rise in Zones 1 and 2 during Period 2, as prices in the other regions fell. The results of the three models support the robustness of the findings in the text.

\section{Appendix 2}

Using the location coordinates and the shape of the communities, as well as the number of samples therein, we randomly generated the coordinates for each house unit by GIS. Spatial weights could then be established in order to conduct a spatial test and spatial regression. The regression results show that the spatial econometric model SEM performs better (see Table A2 and A3). However, the pattern of price gradients of Zones 1-9 with Model 2 and Model 3 are very close to the results in the text. Due to limited space, the results are not shown here and can be provided upon request.

Table A2. Results of regression of different models

\begin{tabular}{|l|c|c|c|c|c|c|c|}
\hline \multirow{2}{*}{ Coefficient } & \multicolumn{3}{|c|}{ Model 1} & Model 2 & Model 3 \\
\cline { 2 - 7 } & Linear & Linear $-\log$ & Log - linear & SAR & SEM & SEM & SEM \\
\hline Constant & $22205.649^{* * *}$ & $30108.698^{* * *}$ & $9.995^{* * *}$ & $2.972^{* * *}$ & $10.566^{* * *}$ & $10.837^{* * *}$ & $10.806^{* * *}$ \\
\hline Size & $-22.814^{* * *}$ & $-1740.935^{* * *}$ & $0.001^{* * *}$ & $-0.096^{* * *}$ & $-0.122^{* * *}$ & $-0.122^{* * *}$ & $-0.124^{* * *}$ \\
\hline Floor/Level No. & $20.424^{* *}$ & $190.989^{* *}$ & $-0.001^{* * *}$ & $0.011^{* * *}$ & $0.012^{* * *}$ & $0.012^{* * *}$ & $0.013^{* * *}$ \\
\hline Total floors & $-32.672^{* * *}$ & $-652.257^{* * *}$ & $-0.002^{* *}$ & $-0.052^{* * *}$ & $-0.102^{* * *}$ & $-0.099^{* * *}$ & $-0.100^{* * *}$ \\
\hline Building's age & $-30.326^{* * *}$ & $235.921^{* *}$ & -0.001 & $-0.013^{* * *}$ & $0.028^{* * *}$ & $-0.036^{* * *}$ & $-0.030^{* * *}$ \\
\hline Distance to CBD & $-789.131^{* * *}$ & $-4095.293^{* * *}$ & $-0.046^{* *}$ & $-0.046^{* * *}$ & $-0.219^{* * *}$ & $-0.291^{* * *}$ & $-0.282^{* * *}$ \\
\hline Distance to West Intime & $-305.480^{* * *}$ & $-1893.405^{* * *}$ & $-0.018^{* * *}$ & $-0.037^{* * *}$ & $-0.136^{* * *}$ & $/$ & $/$ \\
\hline Distance to Xicheng Square & $-327.487^{* * *}$ & $-959.592^{* * *}$ & $-0.015^{* * *}$ & $-0.008^{*}$ & $-0.030^{*}$ & -0.019 & -0.013 \\
\hline External environment & $718.103^{* * *}$ & $730.509^{* * *}$ & $0.047^{* * *}$ & $0.015^{* * *}$ & $0.068^{* * *}$ & $0.076^{* * *}$ & $0.073^{* * *}$ \\
\hline Inner environment & $-284.909^{* * *}$ & $-366.970^{* * *}$ & $-0.016^{* * *}$ & -0.002 & -0.005 & $-0.018^{*}$ & -0.014 \\
\hline Living facilities & $-181.152^{* * *}$ & $-92.520^{*}$ & $-0.013^{* * *}$ & -0.003 & -0.004 & $-0.025^{* *}$ & $-0.026^{* * *}$ \\
\hline Sports facilities & $300.827^{* * *}$ & $131.780^{* * *}$ & $0.014^{* * *}$ & $0.004^{*}$ & 0.008 & $0.024^{* * *}$ & $0.023^{* * *}$ \\
\hline Property management & $1170.150^{* * *}$ & $1656.332^{* * *}$ & $0.061^{* * *}$ & $0.030^{* * *}$ & $0.081^{* *}$ & $0.060^{* * *}$ & $0.061^{* * *}$ \\
\hline Bus route & $-14.807^{*}$ & $-18.432^{* *}$ & $-0.001^{* * *}$ & $-0.001^{* * *}$ & $-0.005^{* * *}$ & $-0.005^{* * *}$ & $-0.005^{* * *}$ \\
\hline Distance to primary school & $-763.224^{* * *}$ & $-548.397^{* * *}$ & $-0.045^{* * *}$ & $-0.014^{* * *}$ & $-0.026^{* *}$ & $-0.019^{* *}$ & $-0.017^{*}$ \\
\hline
\end{tabular}

2 The high house price in Zone 8 may be because most of the samples are concentrated in the southeast of the ring, which is closer to the city center. The uneven distribution of samples and the difference in house prices in all directions may affect the accuracy of the results. This is the main reason why we have not chosen this division method in the text. 
End of Table A2

\begin{tabular}{|l|c|c|c|c|c|c|c|}
\hline \multirow{2}{*}{ Coefficient } & \multicolumn{5}{|c|}{ Model 1 } & Model 2 & Model 3 \\
\cline { 2 - 7 } & Linear & Linear $-\log$ & Log - linear & SAR & SEM & SEM & SEM \\
\hline $\begin{array}{l}\text { Distance to junior high } \\
\text { school }\end{array}$ & $835.816^{* * *}$ & $613.014^{* * *}$ & $0.044^{* * *}$ & $0.008^{* * *}$ & $0.023^{* *}$ & $-0.047^{* * *}$ & $-0.046^{* * *}$ \\
\hline Quality of primary school & $1534.241^{* * *}$ & $1790.623^{* * *}$ & $0.071^{* * *}$ & $0.026^{* * *}$ & $0.093^{* * *}$ & $0.067^{* * *}$ & $0.067^{* * *}$ \\
\hline Quality of junior high school & 139.638 & 186.550 & $0.038^{* * *}$ & 0.008 & $0.056^{* *}$ & 0.037 & 0.038 \\
\hline Y2 & $-1277.337^{* * *}$ & $-1370.727^{* * *}$ & $-0.067^{* * *}$ & $-0.068^{* * *}$ & $-0.074^{* * *}$ & $/$ & $-0.064^{* * *}$ \\
\hline Y3 & 60.759 & -84.845 & 0.000 & -0.002 & $-0.015^{* * *}$ & $/$ & -0.004 \\
\hline Y4 & $-825.525^{* * *}$ & $-1015.551^{* * *}$ & $-0.046^{* * *}$ & $-0.046^{* * *}$ & $-0.061^{* * *}$ & $/$ & $-0.066^{* * *}$ \\
\hline Y5 & $-745.043^{* * *}$ & $-984.428^{* * *}$ & $-0.048^{* * *}$ & $-0.047^{* * *}$ & $-0.067^{* * *}$ & $/$ & $-0.066^{* * *}$ \\
\hline W_lnprice & $/$ & $/$ & $/$ & $0.755^{* * *}$ & $/$ & $/$ & $/$ \\
\hline LAMBDA & $/$ & $/$ & $/$ & $/$ & $0.803^{* * *}$ & $0.685^{* * *}$ & $0.681^{* * *}$ \\
\hline Adjusted R & 0.591 & 0.587 & 0.644 & 0.709 & 0.722 & 0.734 & 0.728 \\
\hline
\end{tabular}

Note: ${ }^{* *},{ }^{* *}$, and ${ }^{*}$ represent significance at the $1 \%, 5 \%$ and $10 \%$ levels, respectively.

Table A3. Diagnose test for OLS regression of Model 1-3

\begin{tabular}{|c|c|c|c|}
\hline & Model 1 & Model 2 & Model 3 \\
\hline Moran's I (resudals) & $0.223(0.000)$ & $0.118(0.000)$ & $0.114(0.000)$ \\
\hline Lagrange Multiplier (lag) & $5855.282(0.000)$ & $1512.888(0.000)$ & $1434.977(0.000)$ \\
\hline Robust LM (lag) & $169.693(0.000)$ & $3.189(0.074)$ & $2.301(0.129)$ \\
\hline Lagrange Multiplier (error) & $8528.628(0.000)$ & $2386.997(0.000)$ & $2232.014(0.000)$ \\
\hline Robust LM (error) & $2843.040(0.000)$ & $877.298(0.000)$ & $799.337(0.000)$ \\
\hline
\end{tabular}

Note: the number in the parentheses are $\mathrm{p}$ value. 